\title{
Obituary: Prof. K.P. Thomas
}

\section{U.R. Nandakumar ${ }^{1}$}

${ }^{1}$ Department of Plastic Surgery, Cosmopolitan Hospitals (P) Ltd., Trivandrum, Kerala, India

Indian J Plast Surg:2020;53:462-463

Prof. K.P. Thomas, most popularly and fondly known as "KPT," former professor and HOD of plastic surgery of Government Medical College, Kottayam, Kerala, passed away on $20^{\text {th }}$ February 20, 2020, at 10.pm, following illness at Caritas Hospital, Kottayam. He was 81 years old.

Born on December 10, 1938, in Aymanam village on the banks of Meenachil river near Kottayam in Kerala, he received his early education in his village and his high school education in Perumbavoor in Ernakulam district. After his B.Sc. degree, he joined MBBS in B.S. Medical College, West Bengal, in 1958.

After his MBBS from University of Calcutta, he worked in Govt. Medical College, Trivandrum, in the department of general surgery under Prof. P.A. Thomas, the first plastic surgeon of Kerala state, from whom he imbibed an interest in plastic surgery. After his MS in general surgery from Govt. Medical College, Trivandrum, in 1971, he joined as tutor in plastic surgery in Govt. Medical College, Kottayam, to work with another giant, Dr. K.R. Rajappan. In 1972, he got selected for M. Ch in plastic surgery at Madras Medical College under the great Prof. C.R. Sundararajan. He was considered the most talented trainee among his teachers and colleagues alike.

After his M.Ch. he joined back Govt. Medical College, Kottayam, in 1974. From then on, except for a few months at Govt. Medical College, Calicut, with Prof. P.K. Appukuttan, his entire career in plastic surgery was spent in Medical College, Kottayam. He became professor in 1983 till his retirement in 1994.

After his retirement, he worked for a few years in Caritas Hospital in Kottayam.

In the Government Medical College, Kottayam, he was all alone till 1982, when qualified assistants joined him. Till then, single handedly, he performed all plastic surgical operations, outpatient \& inpatient care and management of the department for a long time. Even then, he steadily improved the facilities in the department by obtaining all necessary instruments and equipment. Even in the early 80s, the department at the Government Medical College, Kottayam, had a stock of good equipment like Hifricator, cryosurgery equipment, all fine suture material, various silicone implants, and equipment for operation theater. One will be amazed to see how meticulously he had written the details in the operation register, including that of the technical details, in those days when he was all alone in the department. After 1982, the department made further progress. A separate ward for plastic surgery, first of its kind in a government institution in Kerala, with separate dedicated staff was acquired. A five-bedded burns unit with separate nursing and paranursing staff, again first of its kind in a government institution in Kerala, was attached to the ward. All these were possible just because of the perseverance and strong stand taken by Prof. K.P. Thomas.

M.Ch. course in plastic surgery with one candidate per year was started in 1990. He trained four candidates before he retired in 1994. Dr. Padmakumar, Dr. S Ramakrishnan Nair, Dr. Ibrahimkutty, Dr. Benoy Varghese, myself, Dr. P.C. Kasthri Bai, Dr. N.C. Sreekumar, and Dr. Saramma Varghese had the good fortune of working with him and enjoying his leadership. Many of the plastic surgeons of Kerala would attest that they took up a career in plastic surgery because of his inspiring ways and his influence. For most of his young colleagues, he was like a fatherly figure. He had great affection for his colleagues and students. He used to make them do surgeries and assisted them as well. He even went out of the way to help them by all possible means. He even helped solve the personal problems of some of his colleagues.

For 2 years, he was the medical superintendent of the Govt. Medical College Hospital, Kottayam. During those

\author{
Address for correspondence \\ U.R. Nandakumar, MD, Department \\ of Plastic Surgery, Cosmopolitan \\ Hospitals(P) Ltd., Trivandrum, Kerala, India \\ (e-mail: drurnandakumar@gmail.com).
}

DOI https://doi.org/ $10.1055 / \mathrm{s}-0040-1721516$ ISSN 0970-0358.

published online November 30, 2020 (c) 2020. Association of Plastic Surgeons of India.

This is an open access article published by Thieme under the terms of the Creative Commons Attribution-NonDerivative-NonCommercial-License, permitting copying and reproduction so long as the original work is given appropriate credit. Contents may not be used for commercial purposes, or adapted, remixed, transformed or built upon. (https://creativecommons.org/licenses/by-nc-nd/4.0/)

Thieme Medical and Scientific Publishers Pvt. Ltd. A-12, 2nd Floor, Sector 2, Noida-201301 UP, India 
2 years, he brought a lot of good changes in the system and functioning of the hospital. This was possible because he was a straightforward person with high principles. No one could influence him to do anything which he thought was unjust. The tall figure with an upright posture would invite respect spontaneously from everyone when he walked through the corridors of the hospital, because he was a man with a blemish-free record and clear future vision; on the other hand, this earned him the displeasure of some of his colleagues. But that did not deter him from carrying out his duty as an administrator. He practiced ethics in its truest sense with regard to patient care, training, administration and human relationship.

He was a life member of APSI and former president of Kairali Plastic Surgeons' Association (then called APSI, Kerala Chapter). In 2013, The Kairali Plastic Surgeons' Association honored him with the Lifetime Achievement Award during its annual conference

He was well known for his hilarious nature with patients, colleagues, and students. Wherever he was present, there used to be laughter around. But when it came to maintaining discipline, he was a different character. With patients also, he used to be strict regarding following his instructions. He hated patients smoking and having too many visitors around. We remember how he used to put his hand under the pillow of male patients during ward rounds and invariably retrieve cigarettes, a beedi packet, or a match box. The encounter that followed would have the effect of the patient doing away with smoking, at least, till he was discharged.

One particular aspect of Prof. K.P. Thomas which distinctly differentiated him from many others in the profession and brought the feeling of awe among all who came across him is that he did not like to do private consultation at home, even though it was permitted for government medical college doctors after hospital hours by the government of Kerala. Most of the doctors did have practice in the afternoon. His wife Dr. Achamma, who was also a faculty in the department of Ob \& Gy in Medical College, Kottayam, did not engage in private practice. Both of them would leave the house in the afternoon almost every day and return back only late in the evening. In spite of this, if any inpatient or relative tried to meet him in his house, he or she would never dare to do that again. This nature of his ensured him that he was giving equal consideration to all the patients without any partiality.
Yet another distinguishing character of Prof. KPT is the utmost care he took of the instruments, equipment, and other government supplies. He cared for the instruments and equipment as his own property. When he was in the operation room, he seemed to be always on the lookout for how the instruments are being handled by the nursing and paranursing staff while cleaning and packing. This obsession infected his successors also. While he was hospital superintendent, his assistants learned from him a lot about official procedures and formalities in government administration.

He was a down-to-earth man with great love for nature, gardening, and pets.

His colleagues can never forget the so many special jargons he used to apply during conversation. Only those who had been closely associated with him for long can decode them.

All the successive heads of the department of plastic surgery in Kottayam Medical College gave him due respect always. He was a regular invited guest for all events in the department. After his retirement, whenever any of his colleagues or students visited his house, for which he looked forward to eagerly, he used to be very happy, and the couple used to entertain them very well. Madam was a motherly figure for us.

He has two sons, Mr. Biju Abraham Thomas, who is in Chennai as a senior executive in MRF, and Dr. Binu Joseph Thomas, a maxillofacial surgeon practicing in Kottayam. Both their families are happily settled.

For many years, Prof. KPT suffered from recurrent ureteric calculi, which caused him sudden intolerable pain. This affected his mood a lot. He underwent several surgeries for it. He developed interstitial lung disease a year earlier and was significantly incapacitated. Finally, he developed pneumonia and was dependent on a ventilator, before he eventually succumbed to it.

Prof. K.P Thomas left for his heavenly abode a fully satisfied man, as he did his duty as a loving husband, affectionate father and grandfather, a very caring teacher and boss, and a humane clinician to the best of his ability. He might have left us, but the most handsome smiling face will linger in our minds forever. May his soul rest in peace.

\section{Conflits of Interest}

None declared. 